\title{
Uncinate crisis secondary to low grade glioma: Case report
}

\author{
Crises Uncinadas secundária a um glioma de baixo grau: relato de caso
}

\author{
Neila Clediane de Sousa Menezes ${ }^{1}$, Marcos Vinícius de Souza Vilanova ${ }^{1}$, Mário Luciano de Mélo Silva Júnior ${ }^{1,2,3}$ \\ ${ }^{1}$ Curso de Medicina do Centro Universitário Maurício de Nassau, Recife, Pernambuco, Brasil \\ ${ }^{2}$ Pós-graduação em Neuropsiquiatria e Ciências do comportamento, Universidade Federal de Pernambuco, Recife, \\ Pernambuco, Brasil \\ ${ }^{3}$ Unidade de Neurologia, Hospital da Restauração, Recife, Pernambuco, Brasil
}

\begin{abstract}
Resumo
As crises uncinadas, previamente chamadas de auras olfativas, são crises epilépticas focais sensoriais pouco frequentes na prática clínica, principalmente quando acontecem sem generalização secundária. Este trabalho descreve o caso de uma mulher de 32 anos, com exame neurológico normal, que se apresentou com queixas olfativas, sugestivas de crises uncinadas. A investigação com ressonância magnética revelou uma lesão expansiva temporal direita, cuja biópsia estereotáxica evidenciou um glioma de baixo grau. $\mathrm{O}$ tratamento com carbamazepina controlou as crises num segmento de 6 meses e o optou-se por tratamento expectante. É importante lembrar da possibilidade de epilepsia quando diante de queixas olfativas positivas paroxísticas, e avaliar o sistema nervoso central em busca de causas estruturais.
\end{abstract}

Palavras-chave: Epilepsia do lobo temporal; Ressonância magnética, Glioma

\begin{abstract}
Uncinate seizures, previously known as olfactory auras, are sensory focal epileptic spells that are uncommon in clinical setting, especially when they occur without secondary generalized tonic-clonic seizures. This article describes the case of a 32-year-old woman with normal neurologic examination, who presented with olfactory complaints, suggestive of uncinate seizures. Magnetic resonance imaging revealed a right expansive temporal lesion, which stereotaxic biopsy identified a low-grade glioma. The treatment with carbamazepine controlled the spells in the six months follow-up and no surgical intervention was proposed. It is important to keep in mind the possibility of epilepsy in the face of positive paroxysmal olfactory complaints and to evaluate the central nervous system in order to exclude structural lesions.
\end{abstract}

Keywords: Temporal lobe epilepsy, Magnetic resonance, Glioma

\section{Introduction}

Sensory olfactory focal seizures, previously known as olfactory auras, are paroxysmal events resulting from transient electrical activation of the mesial temporal region of the brain, mainly of the uncinate gyrus. They are clinically manifested on the perception of smells, which usually are unpleasant and last for a few seconds. The close relationship with the para-hippocampal structures can lead to the amnesia of events. ${ }^{1,2}$

Neoplasms, especially glial tumors, are one of the main etiologies for uncinate seizures, but they can be related to other causes such as infections, trauma and hippocampal sclerosis. ${ }^{1,2}$

We describe the clinical and imaging findings of a rare case of uncinate seizure, caused by a low-grade glioma, with good response to antiepileptic therapy.

\section{Case report}

Woman, 32-year-old, previously healthy, presented with complaints of short-lasting, frequent (around eight times a day), paroxysmal episodes of perceiving a "hospital's smell" since two months of admission - she told that had accompanied a 
relative hospitalized for some days in a hospital and associated the occurrence of those smells with memories of that stressful period), short, about 8 times a day. Two weeks before presentation, she reported a headache described as a tension-type one. At physical examination, no signs of motor, sensitive, language or memory deficits were noted. She was submitted to magnetic resonance imaging (MRI) of the brain which revealed a hyperintense T2-weighted temporal expansive lesion (Figure 1) non-contrast-enhancing and T1-perfusion with a "cold" (low capillary density) pattern - suggestive of a low-grade glioma. She performed a CSF study - considering the possibility of a viral encephalitis which was normal.

She underwent stereotactic biopsy of the lesion, which confirmed our hypothesis of low-grade glioma and due to large dimensions of the tumor, no surgical intervention was proposed. Clinical treatment with carbamazepine $600 \mathrm{mg} /$ day resulted in a complete resolution of the paroxysmal episodes in a six months follow-up.

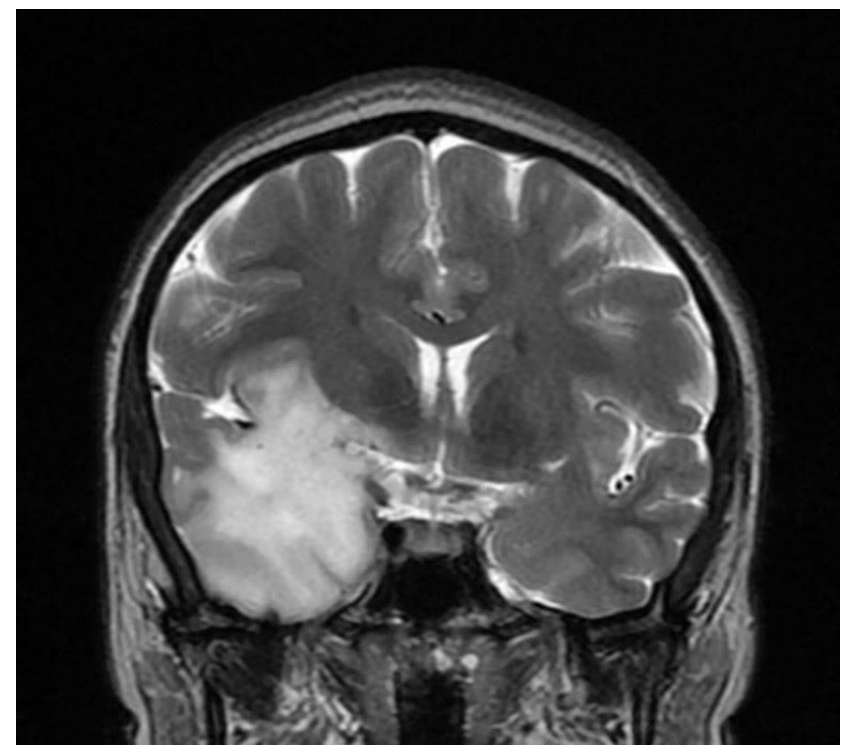

Figure 1 - Magnetic resonance with hyperintense image in T2, right temporal lobe, with frontal extension, suggestive of tumoral lesion.

\section{Discussion}

The initial presentation of an extensive temporal glial tumor with sensory olfactory focal epileptic seizures and normal neurological examination is a rare event. Detailed history and description of the events, preferably obtained from the patient and a witness, can guide the evaluation of the olfactory complaint between rhinological and neurological causes.

The inferior face of the temporal lobe consists of three main grooves: the occipitotemporal, the collateral and the hippocampal. Hippocampal and the collateral grooves delimit two fundamental regions for the olfactory area that are the parahipocampal gyrus (Brodmann's area 34, also known as the primary olfactory cortex) and the anterior region of the soleus (a constituent of the piriform cortex, Brodmann's area 27), part of the limbic associative cortex. ${ }^{4}$ These intimate relations with memory/emotional-related areas and the olfactive cortex may explain the emotional complaints and clinical manifestations reported by our patient. However, amnesia of the event, ictal memories or feelings may also be present. Despite the extent of our patient's lesion, no abnormalities were found on neurological examination and only one clinical initial symptomatic epileptic zone was noted. No electroencephalogram was obtained.

Epileptogenesis in brain tumors is multifactorial but appears to be influenced by the mutation of isocitrate dehydrogenase enzyme, which is commonly found in low-grade gliomas. When mutated, this enzyme produces 2hydroxyglutarate, a molecule similar to the neuroexcitatory amino acid glutamate, generating an environment more prone to epileptic seizures. ${ }^{3}$

These patients should initially be treated with antiepileptic drugs (AED) in monotherapy, mainly with first-line drugs for focal seizures. Drugs such as levetiracetam, lacosamide, valproate and carbamazepine can be used in antiepileptic therapy in this scenario. Levetiracetam showed initial seizure control in up to $91 \%$ of patients, with a good tolerability profile, however patients with temporal lobe tumors may be at higher risk for developing neuropsychiatric effects such as agitation, anxiety and irritability. ${ }^{5,6}$ Lacosamide showed a $66 \%$ decrease in seizure frequency and also good tolerability. ${ }^{7}$ It is an option for venous administration in Brazil. Valproic acid tends to be the drug of choice among many neurologists because it has a histone deacetylase inhibitory effect, which can sensitize glioblastomas to radiotherapy, generating survival benefits in relation to patients who received enzyme-inducing antiepileptic drugs. ${ }^{8}$ On the other hand, valproate can develop more thrombocytopenia and 
leukopenia; also, its use should be avoided in childbearing women ${ }^{8}$. Carbamazepine is also a firstline option for focal epilepsy and, although it causes enzymatic induction - which tends to decrease the serum level of some drugs - it has low cost and extensive clinical experience. ${ }^{9,10}$ There are no randomized studies that demonstrate the superiority of one agent over others, requiring an assessment of individual risk factors and shared decision with patients regarding the risks and benefits of these drugs.

\section{Conclusion}

Uncinate seizures are rare events and brain tumors pose as a major cause of them. Neuroimaging is mandatory in the assessment of these patients. It is important to keep uncinated seizures in mind when facing a patient with olfactory complaints, even with normal neurologic examination.

\section{References}

1. Acharya V, Acharya J, Luders H (1998) Olfactory epileptic auras. Neurology 1:56-60.

2. Yacubian EMT, Koche S. Crises epilépticas. São Paulo: Leitura Médica Ltda., 2014.
3. Cohen A, Holmen S, Colman H (2013) IDH1 and IDH2 Mutations in Gliomas.Curr Neurol Neurosci Rep 13:345.

4. Machado A, Haertel L. Neuroanatomia Funcional. 3 ed. São Paulo: Atheneu, 2013.

5. Rossati, A et al (2010) Efficacy and safety of levetiracetam in patients with glioma: a clinical prospective study. Arch Neurol. 67:343-6.

6. Bedetti, C et al (2017) Neuropsychiatric adverse events of antiepileptic drugs in brain tumour-related epilepsy: an Italian multicentre prospective observational study. Eur J Neurol. 24:1283-1289.

7. Saria, MG et al (2013) Retrospective analysis of the tolerability and activity of lacosamide in patients with brain tumors: clinical article. J Neurosurg 118:1183-7.

8. Weller, M et al (2011) Prolonged survival with valproic acid use in the EORTC/NCIC temozolomide trial for glioblastoma. Neurology 77:1156-64.

9. Glauser, T et al (2013) Updated ILAE evidence review of antiepileptic drug efficacy and effectiveness as initial monotherapy for epileptic seizures and syndromes. Epilepsia 54:551-63.

10. Peruca, E (2013) Optimizing antiepileptic drug treatment in tumoral epilepsy. Epilepsia, 54:97104.

Correspondence:

Mário Luciano de Mélo Silva Júnior mariomelosjr@gmail.com

Received: April 20,2020 Acepted: June 23,2020 